\title{
Economic sanctions and human rights: an analysis of competing enforcement strategies in Latin America
}

\author{
Sanções econômicas e direitos humanos: uma análise de \\ estratégias de proteção competitivas entre si na América Latina
}

http://dx.doi.org/10.1590/0034-7329201400111

CRISTIANE DE ANDRADE LUCENA CARNEIRO*

Rev. Bras. Polit. Int. 57 (1): 197-215 [2014]

\section{Introduction}

This article explores the role of economic sanctions as an instrument of human rights enforcement. It follows the steps of previous research that has focused on the role of international legal institutions, such as human rights treaties (Hathaway 2002, Landman 2005, Simmons 2009); the role of international economic instruments, such as preferential trade agreements (Hafner-Burton 2005); the role of international policymaking tools, such as institutional design (Morrow 2007), foreign policy (Sikkink 2004), and pressure from civil society (Hafner-Burton 2008); the role of domestic political institutions, such as political parties (Vreeland 2008); and the incidence of terror (Dreher, Gassebner and Siemers 2010). This list is not exhaustive. I also rely on more general research on compliance with international agreements, going back to the work of Chayes and Chayes (1995), Downs, Rocke, and Barsoom (1996), Downs (1998), and Downs and Jones (2002) to derive a set of testable hypotheses.

Research on economic sanctions is equally prolific. Scholars seem to agree that they offer a foreign policy instrument of limited success, reaching their stated goals in about $34 \%$ of the cases (Hufbauer, Schott, Elliott et al. 2007). But they nevertheless represent a real threat for the survival of leaders (Marinov 2005; Escriba-Folch and Wright 2010). In fact, all else equal, leaders that were targeted by economic sanctions on a given year are $28 \%$ more likely to be removed from power the following year. Based on this finding by Marinov, others have argued that economic sanctions may have unintended adverse consequences for human rights protection, because distressed leaders tend to engage in more repression

* University of São Paulo (USP), São Paulo, SP, Brazil (cristiane.lucena@usp.br). 
(Carneiro and Elden 2009). Along the same lines, recent work by Peterson (2013) argues that some sanctions are more credible-and thus more likely to bring about a change of behavior on the part of the target-than others. ${ }^{1}$ Drury and $\mathrm{Li}$ (2006) have approached the impact of threats, i.e. the threat of an economic sanction, through the lenses of the relationship between the US and China. There is room in the literature for an analysis that looks into the impact of threats via the diffusion of the same threats in a given region. This paper seeks to contribute to addressing this vacuum, by looking into the economic sanctions that were imposed on countries in the region, during a time when severe violations of human rights constituted a recurrent practice in Latin America.

The broader consequences of economic sanctions for the protection of human rights are at the center of recent work by Reed Wood (2008), which confirms that economic sanctions do have an unintended adverse impact on repression. He focuses on the distinct consequences of sanctions imposed by the United States, as opposed to $\mathrm{UN}$-imposed sanctions. The latter displays the strongest significant impact. In fact, Wood finds that a severe violator of human rights is $25 \%$ more likely to increase the level of repression after the imposition of sanctions by the UN (Wood 2008, 505).

Wood's focus on the UN-US dichotomy leaves a number of questions unanswered. First, I concentrate on sanctions episodes where the very same situation of human rights in the target country motivates the sender. I expect any observable impact to be stronger in this case. Given the state of current research, I do not know if sanctions that targeted the situation of human rights in the receiving countries have had any impact on the level of protection-positive or negative. This question leads to one straightforward hypothesis, which I discuss in more detail below.

Work by Peksen (2009) and by Peksen and Drury (2009) confirm the adverse-though unintended-consequences of economic sanctions for human rights. This research relies on a different measure of human rights protection, the Cingranelli and Richards dataset, but focus on the same group of rights: those associated with physical integrity. Their analysis covers a more recent period in time, confirming that the problem persists, but starts later-thus missing a number of episodes of economic sanctions that are relevant for Latin America, due to limitations on data coverage. Peksen and Drury (2010) also look into the consequences of economic sanctions for democracy, advancing the argument that sanctions reduce political liberties in the target countries through their impact on the leadership. Targeted leaders tighten their repressive apparatus in order to control protests against the economic hardships imposed by sanctions; the same strategy helps them secure their position in power, when faced with growing

1 Timothy Peterson investigates whether US sanctions that were threatened and implemented have a reputationenhancing effect with respect to future threats. This article is an important contribution for a growing research agenda that focuses on the unobservable wheels of compliance. 
threats to their political survival (2010,241). Research by Allen (2008) associates similar consequences to the imposition of economic sanctions, by identifying a higher incidence of protests and riots in the target country as a result of sanctions.

There is however a second research question that is central to the compliance debate: do economic sanctions possess a diffused regional effect so as to bring about higher levels of protection amongst States that were not directly targeted by the sanction? The intuition comes from the work of Marinov (2005), who models the endogenous, empirically unobservable, consequences of economic sanctions. ${ }^{2}$ For him, the most effective sanction produces results without the need to carry out the threat- thus it is never imposed. Does the same framework hold true for sanctions that target human rights protection? I suggest that we can answer this question by looking at the regional consequences of sanctions, drawing from previous research that has analyzed the role of international factors in the creation and sustainability of democracy (Gleditsch and Ward 2006). To that end, I formulate a third hypothesis, also specified in the next section.

The article proceeds as follows: the second section discusses the literature that informs the hypotheses; the third section discusses data, methods, and presents an econometric model; the fourth section presents the analysis; the fifth section presents my results; and the sixth section concludes with directions for further research.

\section{Enforcement mechanisms and human rights obligations}

Three theoretical approaches offer alternative views of the enforcement question with respect to human rights obligations. The first, espoused by Kathryn Sikkink (2004) and Harold Koh (1997, 1998), among others, sees compliance as the result of a social process whereby norms are disseminated amongst activists, decision-makers, legal authorities, and civil society at large. This process operates through the mutual influence of beliefs and preferences, ultimately leading to higher levels of compliance without the need for strict enforcement mechanisms. Chayes and Chayes (1995) summarize the dynamics of compliance with international agreements in different issue areas, and propose that the challenges States encounter with respect to compliance should be managed, rather than addressed in a confrontational manner. Their subsequently labeled "managerial" approach recommends: (a) increased transparency, (b) provision of dispute settlement and capacity-building mechanisms, and (c) a rhetoric that emphasizes persuasion, as the keys to improve compliance levels-including in the realm of human rights protection (Chayes and Chayes 1995, 22-25, 253). They argue the following with respect to the role of enforcement in the promotion of compliance:

2 Jana Von Stein deals with unobservable sources of selection into international legal commitments, and IMF Treaty Article VIII commitments in particular (2005). 
If we are correct that the principal source of noncompliance is not willful disobedience but the lack of capability or clarity or priority, then coercive enforcement is as misguided as it is costly $(1995,22)$.

Speaking about the enforcement of human rights norms, Harold Koh discusses four stages/explanations in the road towards compliance: coincidence, conformity, compliance, and obedience $(1998,1400)$. In his view, the relationship with norm content (or obligation) evolves from a loosely-at times casualobservance of the norm, to the legalization of the expected conduct, and finally to the internalization of norm content. He further asserts that:

...The most effective form of law-enforcement is not the imposition of external sanction, but the inculcation of internal obedience (Koh 1998, 1401).

In parallel to this view, which reserves an important role for civil society and transnational government networks of judges, prosecutors, and advocates, there are two rationalist perspectives. Within these, States are the prominent player and leaders create international institutions to pursue their objectives. Not secondary to their foreign policy goals, political survival is a prominent concern of the leadership (Bueno de Mesquita, Smith, Morrow et al. 2003), who is also conscious of the role States' reputation play in international politics (Downs and Jones 2002).

A summary of the first rationalist approach is offered in Hafner-Burton (2005). The author presents the human rights enforcement problem in terms of two mechanisms of influence: persuasion and coercion. Though she does not see them as mutually exclusive, her analysis sets out to test the strength of these competing enforcement strategies in the context of preferential trade agreements (PTAs). She finds empirical evidence that PTAs that rely predominantly on coercion do better at enforcing the human rights obligations contained in these agreements, which she labels "hard PTAs." These agreements subordinate the continuation of trade privileges to the fulfillment of the human rights improvement clauses provided in the agreement. They operate as positive incentives, while stipulating that if higher levels of human rights protection do not materialize, trade benefits will be withdrawn. All else equal, the results in Hafner-Burton (2005) are statistically significant and reveal that States that signed a hard PTA have a higher probability of reducing their level of repression-when compared to States that belong to a soft PTA.

These are important and encouraging findings, with concrete implications for policymaking. These results take on special relevance if we consider the conclusions reached by Hathaway (2002) and Simmons (2009) with respect to the limited role of treaty ratification when it comes to compliance with human rights agreements. While Hathaway finds that treaty ratification has little impact on human rights protection, a phenomenon that she explains as a logic of expressive (costless) commitment, Simmons focuses on States' motivation to ratify human 
rights agreements, among those, States that have no intention to abandon their repressive behavior. The latter are the so-called "false positives," or countries that sign and ratify international human rights treaties, but have no intention of complying with treaty provisions.

Simmons argues that for false positives, "ratification [...] can be thought of as an act of emulation, in which states 'enact' the values of a broader western progressive culture, in an effort formally to identify themselves as members in 'good standing' of the modern society of states $(2009,5)$." She proceeds to formulate and test a theory of rationally expressive ratification, which offers three possible explanations for "false positives" and their attitude with respect to treaty ratification: (a) these countries may choose to ratify when formal support for the treaty reaches a regional density threshold that makes outsiders stand out and pay high costs for not ratifying (social camouflage); (b) these countries may choose to ratify for reasons of strategic coordination, in order not to miss the opportunity to shape treaty interpretation and renegotiation; or (c) their decision to ratify may be motivated by immediate gratification. Analyzing patterns of ratification for the six core human rights treaties by every country for which data is available, she finds significant results in support of the emulation argument (Simmons 2009, 31).

The emulation argument suggests that similar regional patterns may be a factor in the study of economic sanctions and their impact on the protection of human rights. The Inter-American Human Rights System was created in 1948, with the signature of the American Declaration on Human Rights, which represents a very early development, given the history of the region. The system is subsequently made stronger with the signature of the American Convention on Human Rights (1969), which enters into force in 1978 and launches the "conventional" institutionalization phase of the system (Guerra 2011; Trindade 1997). It is in the shadow of regional and international human rights institutions that countries in the region begin to deal with the question of human rights violations taking place within their own territories. ${ }^{3}$ Thus, exposure to the supranational regimes-both the regional and international human rights regimes, and the very participation in the creation of these institutions, through the negotiation, signature, ratification, and incorporation of treaty obligations-promotes the interaction of governments and civil society vis-à-vis human rights institutions. This process of interaction is relevant, I argue, for the diffusion of norms and best practices as well as for the diffusion of threats. Underlining the individual episodes of economic sanctions imposed with the goal of improving rights protection is a region-wide implicit threat that those countries who continue to torture and to disappear their citizens will be targeted next. I rely on expectations based on this argument to design the empirical part of the analysis. Subsequently, I intend to see if similar effects hold for other regions in the world.

3 Several countries of the region also joined the International Covenant on Civil and Political Rights and its First Optional Protocol, to come under the jurisdiction of the Human Rights Committee soon after (Steiner and Alston 2000). The Committee developed a large caseload involving countries in the region. 
The second rationalist framework is described in Downs, Rocke, and Barsoom (1996). It focuses on the concept of behavior modification as an important variable in the compliance equation. They argue that international agreements that require higher levels of behavior modification on the part of States are less likely to be observed. It follows that existing agreements may meet with higher levels of compliance precisely because they require little behavior modification. ${ }^{4}$ The authors present anecdotal evidence in support of their argument, mostly focusing on environmental and disarmament treaties. A more extensive empirical analysis can be found in Downs (1998).

The intuition in the work by Downs et al. bridges onto economic sanctions via Nikolay Marinov's analysis of selection into observed episodes of economic sanctions (2005). Marinov models three possible instances of economic sanctions:

a) In the first, the incumbent in the target country is strengthened by the sanctions - anticipating this outcome, the sender does not pursue the policy, and sanctions are not imposed.

b) In the second instance, of special interest to my analysis, ...sanctions are very costly for the target's leader. The incumbent is better off conceding the sender's demand for policy change outright. In this case, sanctions are very effective at securing compliance. They are also unlikely to be observed empirically. The targeted government has an incentive to concede without waiting for sanctions to be actually implemented (Marinov 2005, 567).

c) In the third instance, for sake of argument, when sanctions destabilize the leadership in the target country, but not enough to prompt a policy concession. Here, the sender may pursue sanctions as a bargaining tool, or as a way to bring about leadership change. ${ }^{5}$

Economic sanctions fall within the purview of the two rationalist frameworks discussed above, while the operating mechanism behind the threat of sanctions is also explained by the role of policy diffusion, with a greater role for regional organizations (Pevevouse 2002) and international politics (Gleditsch and Ward 2006). In the coercion story, presented by Hafner-Burton (2005), sanctions that target the situation of human rights in the receiving country should lead to higher levels of protection. This leads to the following hypothesis:

\section{H1: Economic sanctions improve the level of human rights protection in the target country}

In the behavior modification story, advocated by Downs, Rocke, and Barsoom (1996), the presence of economic sanctions suggests that the receiving State was

4 At the core of their argument is the plea not to jump to the spurious conclusion that overall compliance with international agreements is high, proposed by Chayes and Chayes (1995).

5 There is an expectation that the new leader will be closer to the sender's preferences with respect to the objectionable policies. On that issue, Marinov's main contribution is the finding that leaders that were targeted by economic sanctions are $28 \%$ more likely to be replaced the following year $(2005,572)$. 
not capable (or was unwilling) of improving the level of rights protection. This leads to the following hypothesis:

\section{H2: Economic sanctions do not improve the level of human rights protection in the target country}

Wood (2008) found some evidence in support of this hypothesis, based on his analysis of sanctions imposed by the US versus sanctions imposed by the UN. Overall, he finds that sanctions have unintended adverse consequences for human rights protection and that those sanctions imposed by the UN are even more harmful, when compared to the ones carried over by the US alone (Wood $2008,505)$. I argue that the presence of economic sanctions may send a signal to other violators in the region and ignite behavior modification on their part. This expectation also follows the logic of compliance with international agreements proposed by Downs, Rocke, and Barsoom (2006) and relies on the emulation argument proposed by Simmons in the context of treaty ratification patterns (2009).

The notion presented in Downs, Rocke, and Barsoom (1996) can shed light on the dynamics of economic sanctions that target human rights protection. Here, we should observe sanctions when countries are unable or unwilling to curtail repression, because sanctions failed to operate as effective deterrents. Alternatively, leaders may decide that the benefits associated with repression are greater than the costs imposed by sanctions. Sanctions are less likely when the challenges for behavior modification are smaller-in other words, when countries are able and/ or willing to improve the level of rights protection. See Table 1.

Table 1. Protection of human rights and the presence of economic sanctions.

\begin{tabular}{|l|c|c|}
\hline & \multicolumn{2}{|c|}{ Challenges for behavior modification } \\
\hline Effective deterrent & Significant & Moderate \\
\hline Presence of sanctions & Less likely & Likely \\
\hline
\end{tabular}

This argument leads to the following hypothesis:

\section{H3: Economic sanctions improve the level of rights protection in countries in the region that were not targeted}

In a nutshell, sanctions' impact on human rights could be studied on countries that were targeted by these sanctions because of their poor record of human rights protection as well as on countries of the same region that were not targeted. In the first situation - wherein countries were targeted because of their human rights record, the model expects to find no effect, because the "firing power" of sanctions disappeared at the very moment they were imposed (Marinov 2005). The second situation, that of countries of the same region that were not targeted, presents us with the opportunity to observe the operation of the threat of sanctions. Here 
the model expects to find a positive effect, in as much as countries will improve their record of rights protection in anticipation of the imposition of sanctions.

\section{Data and methods}

In order to investigate the proposed relationships between economic sanctions and human rights protection, I need data on both. For the former, I use the benchmark study on the effectiveness of economic sanctions by Hufbauer, Schott, Elliott et al. (2007), which covers the period 1914-2004. The database contains information on the goal of the sender, which varies from democratization to border conflicts, narcotics, and human rights, among others. I created a subset of the database, which contains cases where the goal was improvement of human rights protection in the receiving country. I further restricted the geographical scope of the analysis to Latin American countries with a population superior to 500,000 in 2000. My choice to observe countries in Latin America is guided by expectations of strong policy diffusion effects in the region-given the history of the inter-American human rights regime. I was also interested in a group of countries that shared a similar historical background, where the opportunity for policy emulation would be greater. Added to that, the prevalence of the Civil Law tradition in the region controls for intervening factors that I am unable to model at this junction (Simmons 2009). ${ }^{6}$ The data is presented in country-year format and for every year that a country was the subject of economic sanctions the dummy variable is coded 1 . It takes a value of 0 otherwise.

There are several sources of human rights data. Among the most widely used are: (a) Freedom House's civil liberties and political rights scores, available for most countries from 1972 to 2008; (b) the Cingranelli and Richards (CIRI) database on human rights, available from 1981 to 2008; and (c) the Political Terror Scale, available from 1976 to 2007. The main issues involved in choosing the appropriate measure have to do with reliability and coverage. Based on these criteria, I chose to work with the Political Terror Scale (PTS). Aside from its reliability and coverage (1976-2007), it has the advantage of focusing on the most serious violations of human rights, such as political assassinations, political disappearance, and torture. Unfortunately, these are precisely the kinds of human rights violations that motivated the imposition of economic sanctions in Latin America during the time period that I study: 1976-2004. My analysis covers 24 countries over 28 years (841 country-year observations).

PTS is based on annual reports by Amnesty International and the US State Department. It is presented as two separate sets of scores, the first drawn from

6 Simmons argues that Common Law regimes are more resistant to ratifying human rights agreements, even though these countries in general enjoy above-average levels of protection. They represent what she calls "false negatives," or countries that do not join international human rights regimes but that nevertheless protect these rights via domestic law (Simmons 2009). 
Amnesty's reports, which here I call PTSA, the second from analysis put forward by the US State Department (PTSS), in the form of a categorical variable that ranges from 1 (no repression) to 5 (widespread terror). ${ }^{7}$ Following the prevalent practice in the human rights quantitative literature, I control for population, GDP per capita, regime type, and the incidence of conflict. I expect the coefficient of the population variable, which is logged, to be positive, because countries with large populations tend to experience worse levels of rights protection. The reason involves greater competition for scarce resources. I expect GDP per capita to be negatively correlated with the dependent variable: human rights protection, as measured by PTS. We know from previous research that wealthier nations experience higher levels of rights protection, especially in the category of physical integrity rights, such as the right to life and freedom from torture (Poe, Tate, and Keith 1999; David, Gelleny, and Sacko 2001). The GDP per capita values are also logged. Population and GDP data came from Penn World Tables (version 6.2). To control for political regime I use the P2 measure of democracy available in the Polity IV database. The measure ranges from 10 (full autocracy) to 10 (full democracy). The coefficient is expected to be negative, as prior research has found a strong correlation between democracy and higher levels of rights protection. Finally, I also control for civil war and international conflict. This dummy variable is coded 1 if a country was involved in a civil war, and 0 otherwise (data is from version 3.0 of the Correlates of War Intra-State War Data Project). I expect this coefficient to be positive, because instances of civil war and international conflict are often accompanied by higher levels of repression.

Given the nature of the data, I run an ordinal logit regression, with standard errors clustered on country. Descriptive statistics are presented in the appendix. I also run the same model using Freedom House's political rights score. ${ }^{8}$

\section{Economic sanctions in Latin America (1976-2004) - findings and analysis}

During this time period, 12 countries were targeted by economic sanctions because of their record of human rights protection in the region. These sanctions episodes are summarized in Table 2.

\footnotetext{
7 The Political Terror Scale has the following categories: (1) Countries under a secure rule of law, people are not imprisoned for their view, and torture is rare or exceptional. Political murders are extremely rare. (2) There is a limited amount of imprisonment for nonviolent political activity. However, few persons are affected, torture and beatings are exceptional. Political murder is rare. (3) There is extensive political imprisonment, or a recent history of such imprisonment. Execution or other political murders and brutality may be common. Unlimited detention, with or without a trial, for political views is accepted. (4) Civil and political rights violations have expanded to large numbers of the population. Murders, disappearances, and torture are a common part of life. In spite of its generality, on this level terror affects those who interest themselves in politics or ideas. (5) Terror has expanded to the whole population. The leaders of these societies place no limits on the means or thoroughness with which they pursue personal or ideological goals (Gibney, Cornett, and Wood 2008, retrieved from the Political Terror Scale website, accessed at <http://www.politicalterrorscale.org>, on July 3, 2009).
}

8 All statistical tests were conducted using Stata 8 and 10. 


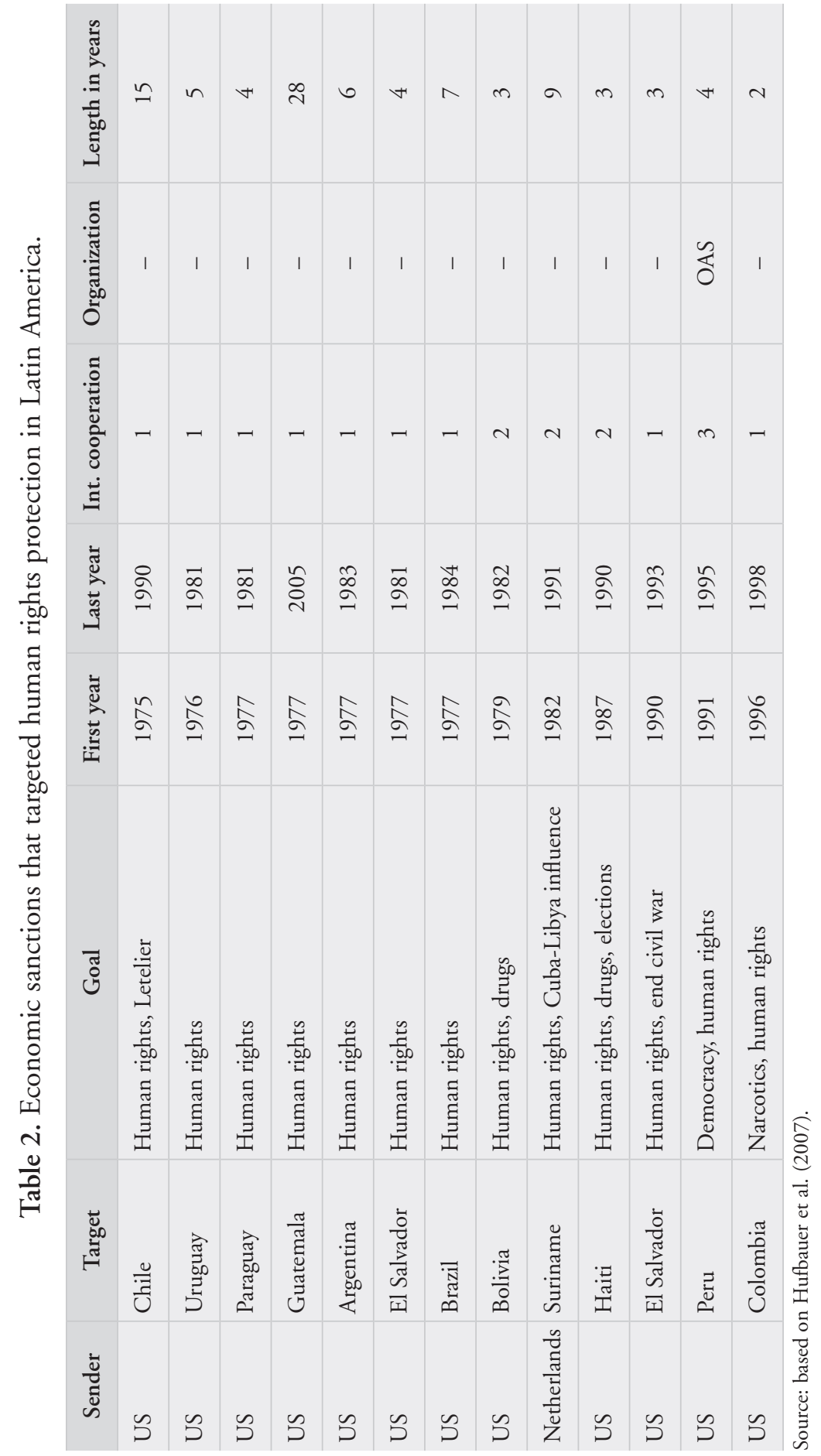


Clearly, the US is behind almost every instance of economic sanctions, and 7 of the 12 sanctions were imposed during the Carter administration ( 5 of the 7 took place on the same year, 1977). Among the 24 countries analyzed in this paper, 12 were targeted by economic sanctions at least once between 1970 and 2004.

The prominent role of the US follows from a shift in foreign policy that preceded the Carter administration. During the Nixon and Ford administrations, Congress slowly claimed and was granted a greater role in foreign policymaking. The advocacy of a small group of congressmen successfully placed the human rights issue on the table and demanded more stringent measures from the Executive. Sikkink argues that a shift in policy towards regional trends in repression started to take place, whereby Congress enacted several measures to pressure dictators in Chile, Argentina, and Guatemala to communicate that the US would no longer endorse indiscriminate and illegal repression in the name of national security $(2004,103) .{ }^{9}$ However, during the years immediately before Jimmy Carter took office, the White House was still reluctant to endorse greater rights protection at any cost. These mixed signals had pervasive consequences and jeopardized the impact of congressional measures, Sikkink argues.

When Carter is inaugurated a more consistent message is voiced. With it, five serious violators of human rights are targeted by economic sanctions on the same year of 1977: Argentina, Brazil, El Salvador, Guatemala, and Paraguay. The late 1970s also coincides with the peak of repression in several countries, including Argentina, where civil society had an important role from the very beginning.

The combination of pressure from international organizations and domestic groups within repressive regimes, the US Congress, and ultimately President Carter's administration could not have gone unnoticed by other countries in Latin America. These were not amongst the worse repressive regimes, and some may have been even democratic, but human rights violations still occurred under these governments. For the purposes of the emulation argument discussed above, these countries understood the shift in signals and policies. I argue that they were ripe to yield to the deterrent effects that economic sanctions carried over. From a methodological standpoint, summary statistics presented in the next section confirm that, with the exception of Costa Rica, there was plenty of room for improving rights protection in the remaining 11 countries that were not targeted by economic sanctions between 1970 and 2004 .

9 Sikkink explains that "the initial human rights legislation, passed in the US Congress in 1974 and 1975 , called on the State Department to produce human rights reports and tied US security assistance to recipients' records on human rights $(2004,106)$." 


\section{Results}

The results confirm the third hypothesis formulated above. The 12 Latin American countries that were not targeted by economic sanctions between 1970 and 2004 saw their level of rights protection improve during this time period; the empirical analysis conducted here suggests that this result is related to sanctions imposed in neighboring countries. I tested the hypothesis using PTS data based on reports by the State Department (PTSS), using PTS data based on reports by Amnesty International (PTSA), and using data from Freedom House's political rights scores. In all three models summarized in Table 3 the signs of the coefficients are in the right direction. The first model is the most significant, but the third model also meets the 5\% threshold for rejection of the null hypothesis ( $p$ value within brackets).

Table 3. Ordered logit outcomes (standard errors clustered on country).

\begin{tabular}{|l|c|c|c|}
\hline Independent variables & Model 1/PTSS & Model 2/PTSA & Model 3/FHPR \\
\hline Sanction & $\begin{array}{l}-0.6674938^{* *} \\
(0.2217266)\end{array}$ & $\begin{array}{l}-0.4661702 \\
(0.3788119)\end{array}$ & $\begin{array}{l}-0.3488869^{* *} \\
(0.1704335)\end{array}$ \\
\hline CivilWar & 1.090331 & $2.859649^{* * *}$ & -0.2622011 \\
\hline LogPop & $(0.7167279)$ & $(0.7270238)$ & $(0.610195)$ \\
\hline LogPCGDP & $1.916865^{* * *}$ & $2.197878^{* * *}$ & 0.5290469 \\
\hline PolityIV & $(0.4881473)$ & $(0.4452644)$ & $(0.5525249)$ \\
\hline N & -1.121413 & $-1.953629^{* * *}$ & -1.046891 \\
\hline & $(0.7874222)$ & $(0.837183)$ & $(1.096679)$ \\
\hline
\end{tabular}

${ }^{*} \mathrm{p}<0.05 ;{ }^{* *} \mathrm{p}<0.01 ;{ }^{* * *} \mathrm{p}<0.001$.

The analysis of the coefficients in Table 4, which presents the odds of a change of category in the PTSS scale in percentage points, reveals that the impact of economic sanctions is not trivial. The presence of economic sanctions in a given year increases the probability of improvement in human rights protection by almost $50 \%$. More specifically, when sanctions are imposed, a country has a $48.7 \%$ greater chance of moving to a lower category in the PTS scale, as compared to the baseline probability. These results hold for all 12 countries that were not subject to economic sanctions, as explained above. 
Table 4. Percentage change in odds.

\begin{tabular}{|c|c|c|c|c|c|c|}
\hline PTSS & b & z & $P>|z|$ & $\%$ & $\%$ StdX & SDofX \\
\hline Sanction & -0.66749 & -2.740 & 0.003 & -48.7 & -25.8 & 0.4478 \\
\hline Loggdppc & -1.12141 & -2.212 & 0.154 & -67.4 & -23.1 & 0.2340 \\
\hline Logpop & 1.91686 & 8.384 & 0.000 & 580.0 & 178.6 & 0.5345 \\
\hline PolityIV & -0.11522 & -5.940 & 0.000 & -10.9 & -50.8 & 6.1603 \\
\hline Civilwar & 1.09033 & 0.819 & 0.128 & 197.5 & 8.8 & 0.0774 \\
\hline
\end{tabular}

$\mathrm{b}=$ raw coefficient.

$\mathrm{z}=\mathrm{z}$-score for test of $\mathrm{b}=0$.

$\mathrm{P}>|\mathrm{z}|=\mathrm{p}$-value for $\mathrm{z}$-test.

$\%=$ percent change in odds for unit increase in X.

$\%$ StdX $=$ percent change in odds for SD increase in $\mathrm{X}$.

SDofX $=$ standard deviation of $\mathrm{X}$.

With the exception of "civil war" and "per capita GDP," all other control variables are significant and signed as expected: as population increases, countries move upward alongside the PTS scale; conversely, as countries become more democratic, they reach lower PTS scores-thus confirming improvements in rights protection.

These results are robust to year trends. Separate tests were conducted for every year included in the analysis, using dummy variables. With the exception of 1977, every other year observation does no produce significant results when regressed against the dependent variable of interest: PTSS. The year of 1977 corresponds to the moment in time when the Carter Administration imposed economic sanctions on no less than five countries in Latin America. My results for this particular year observation are significant at the $10 \%$ level.

In what follows I calculate the predicted probabilities of change from one category in the PTS scale to another category, immediately worse, as a function of the presence of economic sanctions in a given year. There is a clear threshold wherein countries that were not targeted by economic sanctions shift behavior, with respect to the presence of economic sanctions in the region. This threshold is around the mean PTSS value in the data: 2.38 (a little over one third of the way onto category 3, from category 2). As shown in Table 5, the presence of economic sanctions in a given year decreases the probability of observing a PTSS score of 3 and 4 by $14 \%$ and $2 \%$, respectively. These two categories are particularly relevant in my dataset, where PTSS values cluster around categories 2 and 3. 
Table 5. Predicted probabilities of change in the PTSS scale.

\begin{tabular}{|l|c|c|c|c|c|}
\hline & PTSS=1 & PTSS=2 & PTSS=3 & PTSS=4 & PTSS=5 \\
\hline Sanction=0 & 0.0921 & 0.4212 & 0.4460 & 0.0359 & 0.0048 \\
\hline Sanction=1 & 0.1651 & 0.5077 & 0.3059 & 0.0188 & 0.0025 \\
\hline
\end{tabular}

I was not able to confirm the two hypotheses that investigate the impact of economic sanctions on the level of rights protection in the 12 countries that were targeted by sanctions. These results are not surprising, as a finding in the other direction would be at stakes with solid research by Reed Wood (2008), Peksen (2009), and by Peksen and Drury (2009) that has already established the negative impact that economic sanctions have on human rights. The present project sought to investigate whether these findings were true for a subset of sanctions episodes - those imposed because of the poor record of rights protection in the target country. With respect to the second hypothesis, which looks for a nil (or potentially, adverse) impact of sanctions on the level of human rights protection in the target country, without reading too much into results that are not statistically significant in the context of a paper where the empirical analysis is subsidiary to the theoretical argument, the "no finding" is not surprising either. In fact, the expectation derived from the behavior modification model is that sanctions would not produce any consequences in this scenario; this is so because once imposed, sanctions would have lost their capacity to enact behavior modification on the part of the target (Marinov 2005). I believe further thinking on model specification, as well as on omitted variables of interest, may be the next steps in this research agenda.

\section{Conclusion}

I started this investigation with the goal of uncovering the consequences of economic sanctions for the protection of human rights-within countries that were targeted precisely because of their poor record of human rights protection. The literature on sanctions and compliance informed three hypotheses, which dealt with the relationship between sanctions and the level of rights protection in two groups of countries: those that were targeted by sanctions and those that were not. Using data from the Political Terror Scale and from Freedom House, I found empirical evidence suggesting that sanctions do improve the level of protection in countries that were not targeted.

This finding can be explained by the deterrent effect attributed to sanctions by the compliance literature, broadly interpreted. The work of Nikolay Marinov (2005) pioneered this interpretation by modeling three situations involving 
sanctions to find that in one such situation-when sanctions are imposed-, significant threats to leadership survival ensue. In this pilot project, the explanation I offer is coupled with the emulation argument, fully developed by Beth Simmons (2009) in the context of States' patterns of ratification of human rights agreements. I argue that similar effects are at play in Latin America, given the common historical background of countries in the region, especially during the second half of the $20^{\text {th }}$ Century, when a number of them became repressive dictatorships.

This research contributes to a growing literature on compliance with human rights obligations, and specifically to a subset of this literature that focuses on the role of economic sanctions, in as much as the paper proposes an alternative causal mechanism whereby economic sanctions would operate as a threat within the geographical limits of a region. This impact would operate through mechanisms of policy diffusion similar to the ones studied by Gleditsch and Ward (2006) with respect to democracy.

If my findings with respect to countries that were not targeted hold true for a larger set of regions and countries, we may have uncovered a particularly useful side of sanctions, when it comes to human rights protection. So far the literature on economic sanctions has looked down upon its record of success. For the most part, scholars seem to agree that they reach their stated goal in about $30 \%$ of the cases. ${ }^{10}$ But if we analyze only episodes of economic sanctions where human rights protection was among the sender's goals, perhaps we will find better results. In any event, for human rights scholars the findings reported here may launch promising new venues for research and policymaking.

For scholars interested in Latin America and in particular for those interested in human rights protection in the region, my findings warrant revisiting certain skepticism towards sanctions, as foreign policy instruments. After all, an increase in the probability of reaching a better level of rights protection in such a conservative measure as the PTS scale by almost $50 \%$ is no trivial finding. Historically, the economic sanctions that started right before the Carter administration, peaked in 1977, and continued throughout the late 1990s with less strength seem to have helped prevent the spread of the wave of repression, and even motivated countries, through the operation of credible threats, to improve their own level of rights protection. 


\section{Appendix}

\begin{tabular}{|c|c|c|c|c|c|c|}
\hline \multicolumn{7}{|c|}{ Ologit PTSS Sanction CivilWarLogPopLogPCGDPPolityIV, vce(cluster Country) } \\
\hline \multicolumn{5}{|c|}{ Ordered logistic regression } & \multicolumn{2}{|c|}{ Number of obs $=333$} \\
\hline \multicolumn{7}{|c|}{ Wald chi2(4) = . } \\
\hline \multicolumn{7}{|c|}{ Prob $>$ chi $2=$. } \\
\hline \multicolumn{5}{|c|}{ Log pseudolikelihood $=-349.89096$} & \multicolumn{2}{|c|}{ Pseudo R2 $=0.1602$} \\
\hline \multicolumn{7}{|c|}{ (Std. Err. adjusted for 12 clusters in Country) } \\
\hline \multicolumn{7}{|c|}{ Robust } \\
\hline PTSS & Coef. & Std.Err. & $\mathbf{z}$ & $P>|z|$ & \multicolumn{2}{|c|}{ [95\% Conf. Interval] } \\
\hline Sanction & -0.6674938 & 0.2217266 & -3.01 & 0.003 & -1.10207 & -0.2329177 \\
\hline CivilWar & 1.090331 & 0.7167279 & 1.52 & 0.128 & -0.3144302 & 2.495092 \\
\hline LogPop & 1.916864 & 0.4881473 & 3.93 & 0.000 & 0.9601133 & 2.873616 \\
\hline LogPCGDP & -1.121413 & 0.7874222 & -1.42 & 0.154 & -2.664732 & 0.4219065 \\
\hline PolityIV & -0.1152197 & 0.0310586 & -3.71 & 0.000 & -0.1760935 & -0.0543459 \\
\hline
\end{tabular}

\section{Summary statistics}

\begin{tabular}{|c|c|c|c|c|c|}
\hline Variable & Obs & Mean & Std. Dev. & Min & Max \\
\hline PTSS & 342 & 2.385965 & 0.8614464 & 1 & 5 \\
\hline Sanction & 420 & 0.2571429 & 0.4375801 & 0 & 1 \\
\hline LogPop & 420 & 3.6796 & 0.5355523 & 2.843924 & 5.024071 \\
\hline LogPCGDP & 411 & 3.525086 & 0.2851152 & 2.712001 & 4.294316 \\
\hline CivilWar & 420 & 0.0047619 & 0.0689242 & 0 & 1 \\
\hline PolityIV & 420 & 3.671429 & 6.477547 & -8 & 10 \\
\hline
\end{tabular}




\section{References}

Abouharb, Rodwan and David Cingranelli. 2006. "The Human Rights Effects of World Bank Structural Adjustment, 1981-2000.” International Studies Quarterly 50(2), pp. 233-262.

Allen, Susan H. 2008. “The Domestic Political Costs of Economic Sanctions.” Journal of Conflict Resolution 52(6), pp. 916-944.

Box-Steffensmeier, Janet M. Henry E. Brady and David Collier, Eds. 2008. The Oxford Handbook of Political Methodology. Oxford, New York: Oxford University Press.

Bueno de Mesquita, Bruce. George Downs, Alastair Smith, FeryalCherif. 2005. "Thinking Inside the Box: A Closer Look at Democracy and Human Rights." International Studies Quarterly 49(3), pp.439-458.

Bueno de Mesquita, Bruce. Alastair Smith, Randolph Siverson, and James Morrow. 2003. The Logic of Political Survival. Cambridge, MA: MIT Press.

Carneiro, Cristiane and Dominique Elden. 2009. "Economic Sanctions, Leadership Survival, and Human Rights." University of Pennsylvania Journal of International Law 30(3).Forthcoming Spring issue.

Chayes, Abram and Antonia Chayes. 1995. The New Sovereignty: Compliance with International Regulatory Agreements. Cambridge, M.A.: Harvard University Press.

Cortright, David and George A. Lopez. 2000. The Sanctions Decade: Assessing UN Strategies in the 1990s. Boulder, CO: Lynne Rienner Publishers.

Davenport, Christian. 2004. "The Promise of Democratic Pacification: An Empirical Assessment." International Studies Quarterly 48(3), 539-560.

Downs, George and Michael Jones. 2002. "Reputation, Compliance, and International Law." Journal of Legal Studies 31(January), pp. 95.

Downs, George. 1998. "Enforcement and the evolution of cooperation." Michigan Journal of International Law 19(2): 319-344.

Downs, George. David Rocke, and Peter Barsoom. 1996. "Is the good news about compliance good news about cooperation?” International Organization 50(3): 379-406.

Dreher, Axel. Martin Gassebner and Lars-H. Siemers. 2010. "Does Terror Threaten Human Rights? Evidence from Panel Data.” Journal of Law and Economics, 53(1), pp. 65-93.

Drury, A. Cooper and Yitan, T. Li. 2006. "US Economic Sanctions Threats Against China: Failing to Leverage Better Human Rights.” Foreign Policy Analysis 2(4), pp. 307-324.

Escriba-Folch, Abel and Joseph Wright. 2010. "Dealing with Tyranny: International Sanctions and the Survival of Authoritarian Rulers.” International Studies Quarterly Vol. 54, pp. 335-359.

Gibney, M., Cornett, L. and Wood, R. 2008. Political Terror Scale 1976-2006. Retrieved from the Political Terror Scale website, available at $\langle$ http://www.politicalterrorscale.org $>$, accessed on July 3, 2009.

Gleditsch, Kristian and Michael D. Ward. 2006. "Diffusion and the International Context of Democratization.” International Organization 60(4), pp. 911-933.

Guerra, Sydney. 2011. Direito Internacional dos Direitos Humanos. São Paulo, S.P.: Ed. Saraiva.

Hafner-Burton, Emilie. 2009. "Naming and Shaming and the Human Rights Enforcement Problem. International Organization, forthcoming. 
2005. "Trading Human Rights: How Preferential Trade Agreements Influence Government Repression.” International Organization 59(Summer), pp. 593-629.

Hathaway, Oona. 2002. "Do human rights treaties make a difference?” The Yale Law Journal 111(8): 1935-2043.

Hufbauer, Gary C., Jeffrey J. Schott, Kimberly A. Elliott, and Barbara Oegg. 2007. Economic Sanctions Reconsidered. Washington, D.C.: Peterson Institute for International Economics.

Koh, Harold. 1998. "How is International Human Rights Law Enforced?” Indiana Law Journal 74, p. 1397.

Lacy, Dean and Emerson Niou. 2004. "A Theory of Economic Sanctions and Issue Linkage: The Roles of Preferences, Information, and Threats." The Journal of Politics 66(1), pp. 25-42.

Landman, Todd. 2005. Protecting Human Rights. A Comparative Case Study. Washington, D.C.: Georgetown University Press.

Lektzian, David and Mark Souva. 2003. "The Economic Peace between Democracies: Economic Sanctions and Domestic Institutions.” Journal of Peace Research 40(6), pp. 641-660.

Marinov, Nikolay. 2005. "Do Economic Sanctions Destabilize Country Leaders?” American Journal of Political Science 49(3), pp. 564-576.

McGillivray, Fiona and Allan Stam. 2004. "Political Institutions, Coercive Diplomacy, and the Duration of Economic Sanctions." The Journal of Conflict Resolution 48(2), pp. 154-172.

Morrow, James D. 2007. "When Do States Follow the Laws of War?” American Political Science Review 101(3), p. 559.

Pape, Robert. 1997. "Why Economic Sanctions Do Not Work?” International Security 22(2), pp. $90-136$.

Peksen, Dursun and A. Cooper Drury. 2010. "Coercive or Corrosive: The Negative Impact of Economic Sanctions on Democracy.” International Interactions 36(3), pp. 240-264.

Peksen, D. 2009. "Better or Worse? The Effect of Economic Sanctions on Human Rights." Journal of Peace Research 46(1), pp. 59-77.

Peksen, Dursun and A. Cooper Drury. 2009. "Economic Sanctions and Political Repression: Assessing the Impact of Coercive Diplomacy on Political Freedoms." Human Rights Review 10(3), pp. 393-411.

Peterson, Timothy M. 2013. "Sending a Message: The Reputation Effect of US Sanction Threat Behavior.” International Studies Quarterly 57(3), pp. 672-682.

Poe, C. S. C. N. Tate, and Linda C. Keith. 1999. "Repression of the Human Right to Physical Integrity Revisited: A Global Cross-National Study Covering the Years 1976-1993.” International Studies Quarterly 43, pp. 291-313.

Richards, David. Ronald Gelleny, and David Sacko. 2001. "Money with a Mean Streak? Foreign Economic Penetration and Government Respect for Human Rights in Developing Countries." International Studies Quarterly 45, pp. 219-239.

Sarkees, Meredith Reid (2000). "The Correlates of War Data on War: An Update to 1997," Conflict Management and Peace Science, 18/1: 123-144.

Steiner, Henry J. and Philip Alston. 2000. International Human Rights in Context: Law, Politics, Morals. Oxford: Oxford University Press.

Sikkink, Kathryn. 2009. "From State Responsibility to Individual Criminal Accountability: A New Regulatory Model for Core Human Rights Violations. Manuscript on file with the author. 
University Press.

2004. Mixed Signals: U.S. Human Rights Policy in Latin America. Ithaca, NY: Cornell

Simmons, Beth. 2009. Mobilizing for Human Rights: International Law in Domestic Politics. Cambridge, M.A.: Cambridge University Press.

Trindade, Antônio Augusto Cançado. 1997. Tratado de Direito Internacional de Direitos Humanos. Porto Alegre, M.G.: Ed. Sérgio Fabris.

Von Stein, Jana. 2005. "Do Treaties Constrain or Screen? Selection Bias and Treaty Compliance." American Political Science Review 99(4), pp. 611-622.

Vreeland, James R. 2008. "Political Institutions and Human Rights: Why Dictatorships Enter into the United Nations Convention Against Torture." International Organization 62, Winter, pp. 65-101.

Wood, Reed. M. 2008. "A Hand upon the Throat of the Nation: Economic Sanctions and State Repression.” International Studies Quarterly 52, pp. 489-513.

Submitted May 29, 2014

Accepted May 29, 2014

\begin{abstract}
This article addresses the consequences of economic sanctions for the protection of human rights in Latin America. The literature on sanctions and compliance informs three hypotheses, which investigate the relationship between sanctions and the level of rights protection in two groups of countries: those that were targeted by sanctions and those that were not. Using data from the Political Terror Scale (PTS) and from Freedom House, I find empirical evidence that sanctions do improve the level of protection in countries that were not targeted. This finding can be explained by the deterrent effect attributed to sanctions by the compliance literature, broadly interpreted. The presence of economic sanctions in a given year increases the probability of observing better human rights practices by almost 50\%. These results hold for the 12 Latin American countries that were not subject to economic sanctions for the period 1976-2004.
\end{abstract}

Keywords: economic sanctions; human rights; Latin America.

\title{
Resumo
}

O presente artigo trata das consequências das sanções para a proteção dos direitos humanos na América Latina. A literatura sobre sanções econômicas e sobre cumprimento orienta três hipóteses, que investigam a relação entre sanções econômicas e o nível de proteção aos direitos humanos em dois grupos de países: aqueles que foram objeto de sanções e aqueles que não sofreram sanções. Com base em dados da Political Terror Scale (Escala de Terror Político) e da Freedom House, encontra-se evidência empírica de que sanções melhoram o nível de proteção em países que não foram objeto dessa forma de pressão econômica. Esse resultado pode ser explicado pelo efeito inibidor atribuído às sanções econômicas pela literatura sobre cumprimento. A presença de uma sanção em um dado ano aumenta a probabilidade de se observar melhores práticas de direitos humanos em quase $50 \%$. Esse resultado vale para todos os 12 países latinoamericanos que não foram objeto de sanção no período de 1976-2004.

Palavras-chave: sanções econômicas; direitos humanos; América Latina. 


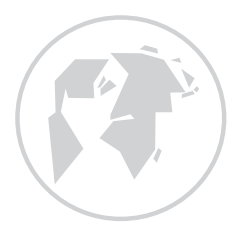

Impresso no Brasil pela Teixeira Gráfica e Editora Ltda., utilizando os papéis Couchê fosco $250 \mathrm{gr}^{2}$ (capa),

Offset $75 \mathrm{gr}^{2}$ (miolo) e composto com as fontes AGaramond (texto),

Humnist777 BT e Humnist777 Lt BT (títulos e subtítulos) 